\title{
Mapping of groundwater potential zones in hard rock terrain using geoinformatics: a case of Kumari watershed in western part of West Bengal
}

\author{
Prasanta Kumar Ghosh ${ }^{1} \cdot$ Sujay Bandyopadhyay ${ }^{1} \cdot$ Narayan Chandra Jana $^{1}$
}

Received: 21 September 2015/Accepted: 31 October 2015/Published online: 7 December 2015

(C) Springer International Publishing Switzerland 2015

\begin{abstract}
Groundwater is one of the world's most precious natural resources. But still now this valuable resource is largely unexploited for agricultural development in drought prone western region of West Bengal. In drought prone areas micro-watershed based development strategy may be considered as the best practice for integrated development. Keeping in view the above perspective, we select Kumari watershed of Purulia district, the westernmost and semi-arid district of West Bengal for better water resource management. Geologically the area consists of Chotanagpur granite gneiss complex while physiographically it is highly dissected pedimental landscape with lateritic upland and skeletal soil. As a result, cultivation of this area is predominantly mono-cropped and thus per hectare production is also low as compared to other regions of West Bengal. Supply of sufficient water resource in this region may offer more food security alternative to rain-fed subsistence farming. That's why the present study has been carried out to evaluate the potential zones for groundwater targeting in Kumari watershed of Purulia district using an integrated remote sensing data, Survey of India topographical sheets and field verification. Hydro-geological features (geomorphological and geological units, slope, drainage density, lineaments density etc.) that influence groundwater occurrence were extracted and integrated to
\end{abstract}

Prasanta Kumar Ghosh

gprasanta05@gmail.com

Sujay Bandyopadhyay

sujaybandyopadhyayest@gmail.com

Narayan Chandra Jana

jana.narayan@gmail.com

1 Department of Geography, University of Burdwan, Golapbag, Burdwan 713104, West Bengal, India evaluate the hydro-geomorphological characteristics of the study area. Thematic maps of the extracted features were prepared with the help of ERDAS Imagine 9.0 and ArcGIS 9.3 software. Weightage values were assigned to the different parameters according to their relative importance to groundwater potentiality and integrated through Geographic Information System environment. Finally on the basis of grid-wise theme weight and class weights the groundwater potential map was prepared by overlay the thematic layers.

Keywords Groundwater potential - Watershed - Water resource management · Geographic Information System

\section{Introduction}

Groundwater is one of the world's most precious and significant natural resources for sustenance of life and also for any developmental activity (Subba et al. 2001; Hutti and Nijagunappa 2011; Biswas et al. 2012). Due to its several inherent and natural qualities, it has become an important and dependable source of water supplies in all climatic regions including both urban and rural areas of the developed and developing countries (Todd and Mays 2005). But still now, this valuable resource is largely unexploited for agricultural development in drought prone Purulia district in West Bengal of India (MoEF 2011; Kar et al. 2012). After the Central Ground Water Board (CGWB), the state of West Bengal can be divided into three parts based on the yield prospects: (1) areas of prolific ground water resources (yield is more than $150 \mathrm{~m}^{3} / \mathrm{h}$ ); (2) areas with moderate yield (yield between 50 and $150 \mathrm{~m}^{3} / \mathrm{h}$ ); and (3) areas with limited yield prospect (yield less than $50 \mathrm{~m}^{3} / \mathrm{h}$ ). Instead of high annual rainfall $(1331 \mathrm{~mm})$, the western and south- 
western parts of the district are affected by drought and fall under limited yield prospect zone. The high run-off factor controls the ground water resources potentiality due to lithological characteristics. In drought prone areas microwatershed based development strategy may be considered as the best practice for integrated development, as the basic principle of watershed management is to conserve and develop water resources for land resource development. In the present context, for better water resource management we select Kumari watershed (KW) of Purulia district covering Bandoan, Baarabazar, Balarampur, Manbazar-I and II CD Blocks and Patamda Block of Jharkhand district (A 'C.D. block' or community development block is normally Planning and Development unit of a district in India represents a compact area comprising several villages). Literally Bengali word Kumari means Virgin or unproductive. Geologically its location in the cratonic part (Chotanagpur Granite-Gneiss Complex or CGGC) of West Bengal (Fig. 1b), consist of Precambrian metamorphic terrains with low to high-grade crystalline rocks (Sharma 2009), while physiographically it is highly dissected Pedimental landscape with lateritic upland and skeletal soil, which are the responsible factors to make the region barren and unproductive. Groundwater in such terrains occurs in the available openings like joints, fissures, fractures and other planes of weakness and within the weathered residuum at relatively shallow depths. Depths-to-water from the land surface vary widely even within short distances. Groundwater is mainly tapped in such areas through open wells. An ideally constructed open well located at favorable site may yield good quantity of water (Roy 1969) throughout the year, which may convert this region from dull to greenish and may offer more food security alternative to rain-fed subsistence farming. So the present study aims to identify the ground water potential zone of Kumari River basin in Purulia. In that case geoinformatics will be best and important tools, because Geographic Information System (GIS) is considered as a powerful tool in integration and analysis of multi thematic layers in delineating ground water prospect and deficit zones (Carver 1991; Saraf and Chaudhuray 1998; Rokade et al. 2007; Nag 2005; Ganapuram et al. 2009; Magesh et al. 2012; Selvam et al. 2012, 2014). In recent years, extensive use of satellite data along with conventional maps and rectified ground truth data has made it easier to establish the base-line information for groundwater potential zones (Tiwari and Rai 1996; Das et al. 2000; Thomas et al. 1999; Subba et al. 2001; Chowdhury et al. 2010; Magesh et al. 2012). Applications of Remote Sensing and GIS for the exploration of groundwater potential zones are carried out by a number of researchers around the world (which are cited above), but prospective groundwater zones are poorly defined in the hard rock terrain like Kumari Watershed and most of them have tried to find out the pixel-wise groundwater potential zone, which makes the reader and planner confused as it is difficult to identify the location of a pixel in field. That's why we tried to find out the grid wise groundwater potential zone for proper watershed management. Though based on mainly geology, Acharya and Nag (2012, 2013) have great contribution to find out the groundwater potential zone in this area, but in this paper to find out the potential zone, we tried to integrate different factors responsible for groundwater recharge in GIS environment.

\section{Study area}

The Kumari River Basin (a sub-basin of the Kangsabati River) spreading over an area of $1867.258 \mathrm{~km}^{2}$, situated mostly in Purulia district of West Bengal, India (Fig. 1a). Though very small part of the basin area is found in Jharkhand state. SRTM satellite image (Jarvis et al. 2008) shows that the altitude of the basin ranges from 110 to $659 \mathrm{~m}$ above msl (Fig. 1c). Originate from Ajodhya hill in west the river flows towards east (Plate 1) up to Mukutmonipur reservoir, enclosed by Dalma range in the south and Kangsabati River in the north. The Kumari River (total individual length $163.23 \mathrm{~km}$ ), lifeline of the area makes a total run of about $2012.528 \mathrm{~km}$ including all of its tributaries like Hanumata, Sona, Nangasai, Chaka, Totko and Jamuna etc. (Fig. 1c). Northern portion of the study area is a part of the CGGC, consisting varieties of granite gneisses, such as quartz-biotite granite gneiss and porphyroblastic granite gneiss while the Singbhum Group (SG) rocks exposing at the south belongs to Singhbhum orogenic belt and comprises chiefly of mica schist and phyllite (Acharya et al. 2012). The average rainfall of this region is $1330.8 \mathrm{~mm} /$ year (IMD), and the availability of surface water of the river basin as surface flow and storage in reservoirs has been calculated as 653 and 24 million cubic metres (mcm) (Kundu 2004). Inspite of that, cultivation of this region is predominantly mono-cropped and per hec production also low as compared to other regions of West Bengal even people are suffering from water scarcity (Plate 2). The depth of water table in the Kumari River basin ranges from 1 to $7 \mathrm{~m}$ (CGWB) and ground water potential (utilizable) of this river basin has been calculated as $194 \mathrm{mcm}$ whereas the present annual ground water draft is as meager as $10 \mathrm{mcm}$ i.e., only $5 \%$ of utilizable ground water (Kundu 2004). The balance of $184 \mathrm{mcm}$ of groundwater may become potential source for further development of irrigation network. Block wise groundwater availability data (Table 1) also support that exploitation of ground water from suitable sites is possible and may fulfill the demand of thousands of people. That's why the present study has been carried out to evaluate the potential zones 
Fig. 1 Location and drainage system of Kumari River Basin. a Location of Kumari Watershed $(\mathrm{KW})$ in the western part of West Bengal, India. b Location of KW in Indian Craton. Tectonic boundaries are marked in black with ticks on the upthrown side of thrusts. The gray dashed line is the hinge zone indicating the transition between the Indian Craton and the thick sediments of the Bengal basin. National boundaries are indicated by brown lines. c Relief and drainage system of Kumari watershed $(\mathrm{KW})$
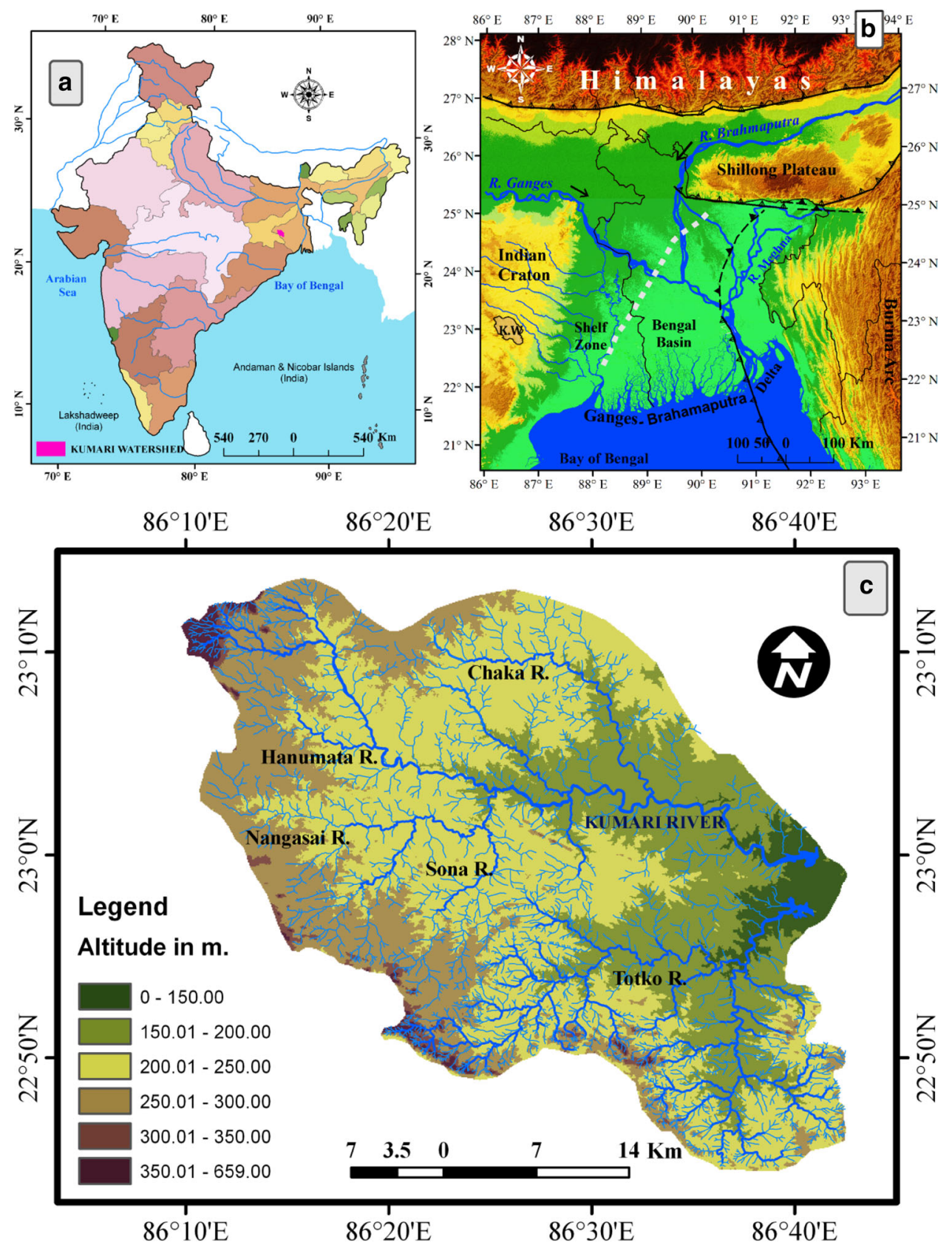

for groundwater targeting in Kumari watershed of Purulia district using an integrated remote sensing data, Survey of India (SOI) topographical sheets and field verification.

\section{Methodology}

The base map of Kumari River Basin has been prepared based on Survey of India (SOI) topographical maps (73I/4, $73 \mathrm{I} / 8,73 \mathrm{I} / 12,73 \mathrm{~J} / 5$, and $73 \mathrm{~J} / 9$ ) on $1: 50,000$ scale and satellite images. Then the whole basin was separated by different grids. Drainage network for the study area was digitized from SOI toposheets using ArcGIS v-9.3. Lineaments were identified by observing the pattern of drainage. The slope map was prepared from SRTM DEM, geological map from Geological Quadrangle Maps (73I and 73J) of Geological Survey of India and soil map from the National Bureau of Soil Survey and Land Use Planning (NBSS\&LUP). Grid wise data were then spatially interpolated using inverse distance weighted (IDW) method and on the basis of that, different thematic maps have been prepared in ArcGIS and ERDAS platform. The Indian 


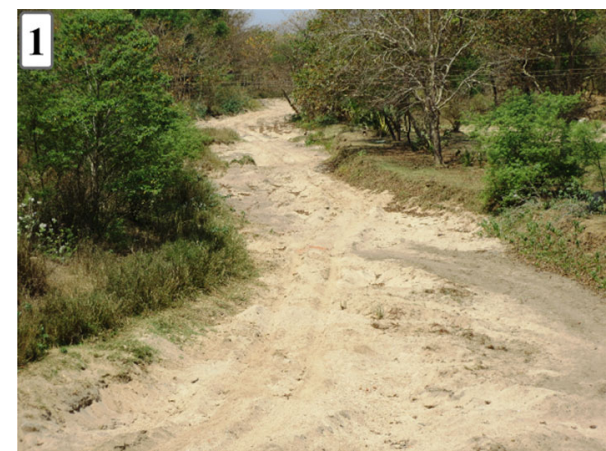

Plate 1 Upstream of Kumari River (lifeline of the area) remains dry in summer months

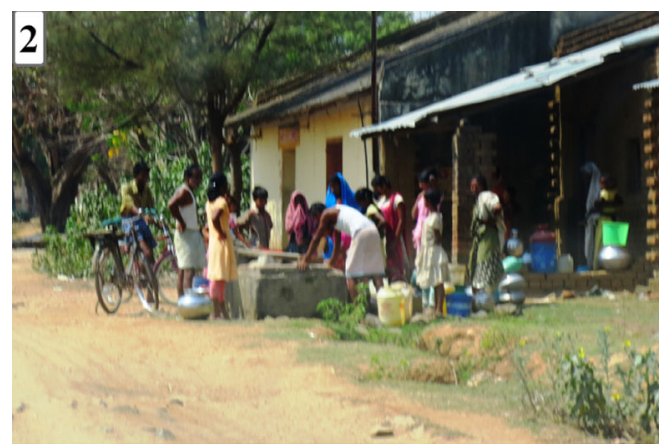

Plate 2 Scarcity of drinking water near Balarampur

Remote Sensing Satellite (IRS) 1C, linear image selfscanning (LISS) III of geo-coded with UTM projection, spheroid and datum WGS-84, Zone North 45 generated from the total bands 4 on a 1:50,000 scales, was used for the land use mapping in present study. The groundwater potential zones were obtained by overlaying all the thematic maps in terms of weighted overlay methods. During weighted overlay analysis, the ranking was given for each individual parameter of each thematic map, and weights were assigned according to the multi influencing factor (MIF) of that particular feature on the hydro-geological environment of the study area (Shaban et al. 2006; Magesh et al. 2012).

\section{Factors influencing ground water potential zone}

Groundwater occurrence being subsurface phenomenon, its identification and location is based on indirect analysis of some directly observed terrain features like geological and geomorphic features and their hydrologic characters (Acharya and Nag 2013). It's occurrence at any place on the earth is a consequence of the interaction of the climatic, geological, hydrological, physiographical and ecological factors (Antony 2012). In this context following six major factors were studied independently, which are effects on groundwater recharge rates.

\section{Lithology}

Lithological character of the exposed rocks is most significant in governing recharge as the other factors are highly dependent on it. Though, because of considering lineament and drainage as a part of lithology some hydrogeologist (Edet et al. 1998) neglected this factor. But others (Salman 1983; Shaban et al. 2006; Magesh et al. 2012; Acharya and Nag 2013) incorporate the lithology factor because of its strong influence on water percolation. It is because of this reason the present study considers lithology as an important factor to minimize the errors instead of using lineaments and drainage factors alone.

Mainly metamorphic rocks of Proterozoic age are present in the study area (Baidya 1992; Acharya and Nag 2013). Ground water in this area normally stored within the weathered and fractured unweathered rocks. The average thickness of this weathered zone varies from 4 to $16 \mathrm{~m}$ (Kundu 2004). In the watershed under study, bedrocks are of Chotanagpur Gneissic Complex (Plate 3), consisting varieties of granite gneisses (i.e. quartz-biotite granite

Table 1 Block wise summary of groundwater resources

\begin{tabular}{|c|c|c|c|c|c|c|}
\hline $\begin{array}{l}\text { Blocks } \\
\text { (within } \\
\text { which KW } \\
\text { fall) }\end{array}$ & $\begin{array}{l}\text { Net } \\
\text { groundwater } \\
\text { availability } \\
\text { (ha m) }\end{array}$ & $\begin{array}{l}\text { Existing gross } \\
\text { groundwater draft } \\
\text { for irrigation } \\
(\text { ha } \mathrm{m})\end{array}$ & $\begin{array}{l}\text { Existing gross } \\
\text { groundwater draft for } \\
\text { domestic and industrial } \\
\text { supply (ha } \mathrm{m} \text { ) }\end{array}$ & $\begin{array}{l}\text { Existing gross } \\
\text { groundwater draft } \\
\text { for all use (ha m) }\end{array}$ & $\begin{array}{l}\text { Net groundwater } \\
\text { availability for future } \\
\text { irrigation development } \\
\text { (ha } \mathrm{m} \text { ) }\end{array}$ & $\begin{array}{l}\text { Stage of } \\
\text { groundwater } \\
\text { development } \\
(\%)\end{array}$ \\
\hline Bandoan & 2947 & 77 & 133 & 210 & 2691 & 7.11 \\
\hline Manbazar-I & 5258 & 157 & 214 & 371 & 4812 & 7.06 \\
\hline $\begin{array}{l}\text { Manbazar- } \\
\text { II }\end{array}$ & 3992 & 24 & 144 & 168 & 3775 & 4.2 \\
\hline Barabazar & 6275 & 248 & 235 & 483 & 5711 & 7.7 \\
\hline Balarampur & 2988 & 263 & 153 & 416 & 2518 & 13.93 \\
\hline
\end{tabular}

Source: CGWB and SWID, Govt. of West Bengal, 2004 


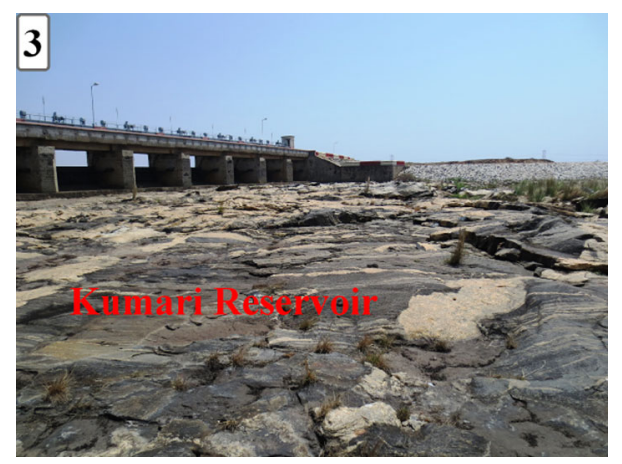

Plate 3 Basement of study area made up of granite and Gneiss

gneiss and porphyroblastic granite gneiss) and the Singhbhum Group of rocks, comprising chiefly of mica schist and phyllite of Proterozoic age (Baidya 1992; Acharya et al. 2012). Geological Quadrangle Map (73I and 73J, 1948), also reveals that, in the north of the study area there are vast exposure of Chhotanagpur Granite Gneiss and other half covered by Mica schist and Shale, which is shown in Fig. 3a. Mica schist and shale contain more weak planes susceptible to develop secondary porosity than granite gneiss. Though, deposition of fine grained materials within the pore spaces of mica schist results in reduction of secondary porosity (Acharya and Nag 2013). In the northern part there are also some depositions of recent alluvium, lithologically which is more suitable for groundwater recharge.

\section{Slope}

Slope is a significant factor for the detection of groundwater prospective zones. It has a dominant influence on the contribution of rainfall to the stream flow and recharge to the groundwater reservoir, in as much as it controls the duration of overland flow, infiltration and subsurface flow. Steeper slopes causes less recharge because of rapid runoff during rainfall, allowing insufficient time to infiltrate the surface and recharge the saturated zone (Rokade et al. 2007; Magesh et al. 2012; Gumma and Pavelic 2012; Selvam et al. 2014). In Kumari watershed slope becomes gentle towards north. Figure $3 \mathrm{~b}$ illustrates the range of slope in the study area. A slope of $<2^{\circ}$ is considered as plain region with lower slope which is usually a very good recharge zone because of low runoff. On the other hand, the areas having a slope of $>5^{\circ}$ are considered as 'very poor' due to higher slope and rapid runoff.

\section{Lineaments}

O'Leary et al. (1976) defined a 'lineament' as a mappable, simple or composite linear feature of a surface, whose parts are aligned in a rectilinear or slightly curvilinear relationship. These factors are hydro-geologically very important as they provide the pathways for groundwater movement (Magesh et al. 2012). Usually, there are three principles regarding the importance of lineaments on groundwater recharge. Some hydro-geologists deal with the connectivity of lineaments, which is only an indicative phenomenon to the groundwater transport, since the connected lineaments create an underground route for groundwater flow (Shaban et al. 2006), while others involve only the length density (Teeuw 1994). The number of lineaments is another applied criterion of analysis. Though in this study we used the second concept because lineament density of an area can indirectly reveal the groundwater potential, since the presence of lineaments usually denotes a permeable zone. Areas with high lineament density are good for groundwater potential zones (Haridas et al. 1998). In this study lineaments were identified from the satellite imagery by observing linear and straight alignments. The lineament density map of the study area is shown in Fig. 3c, and it reveals that high lineament density is observed in the south-western part of the study area with a value greater than $0.5 \mathrm{~km} / \mathrm{km}^{2}$.

\section{Land types and land use/land cover}

Land types from Dongri (hillock) to nala section may be classified as: Dungri-Tanr-Bandh-Kanali-Bahal, which is shown in Fig. 2 (Roy and Chakraborti 2007). 'Tanr' is mainly the barren part, at the slope of hill or dungri. Land immediately below the 'Tanr' land, known as 'Bandh' or 'Baid' or 'Baad' with shallower and gravelly or rocky top soils. 'Bandh' is not all time water saturated. It gets water during monsoon only. Step cultivation is the dominant process of cultivation by making-raised boundaries around sloping sides for water logging. The land then rolls down gradually up to the lowest land (Kanali and Bahal), where top soils are deeper and fertile. In 'Kanali' or 'Ajan' water flows during rainy season only but it is water saturated throughout the seasons. 'Bahal' or 'Garha' with flatter slope is mostly the drainage channel (Plate 4) where water flowing in rainy season and water logging in other times help profusely in cultivation of paddy (Pangare 2003; Roy and Chakraborti 2007). Among these different types of land, Kanali and Bahal have high groundwater potentiality. Beside it, Land use/land cover is a significant factor affecting the recharge process (Shaban et al. 2006; Selvam et al. 2012, 2014). Presence of water bodies, vegetation, soil deposits and human settlements are important elements of this factor. Man-made construction, such as concrete embankments, buildings, hangers, roads etc. and thick accumulations of soil deposits with clay content reduce the rate of water percolation. On the other hand, it is assumed that the vegetation cover has effective role in the 


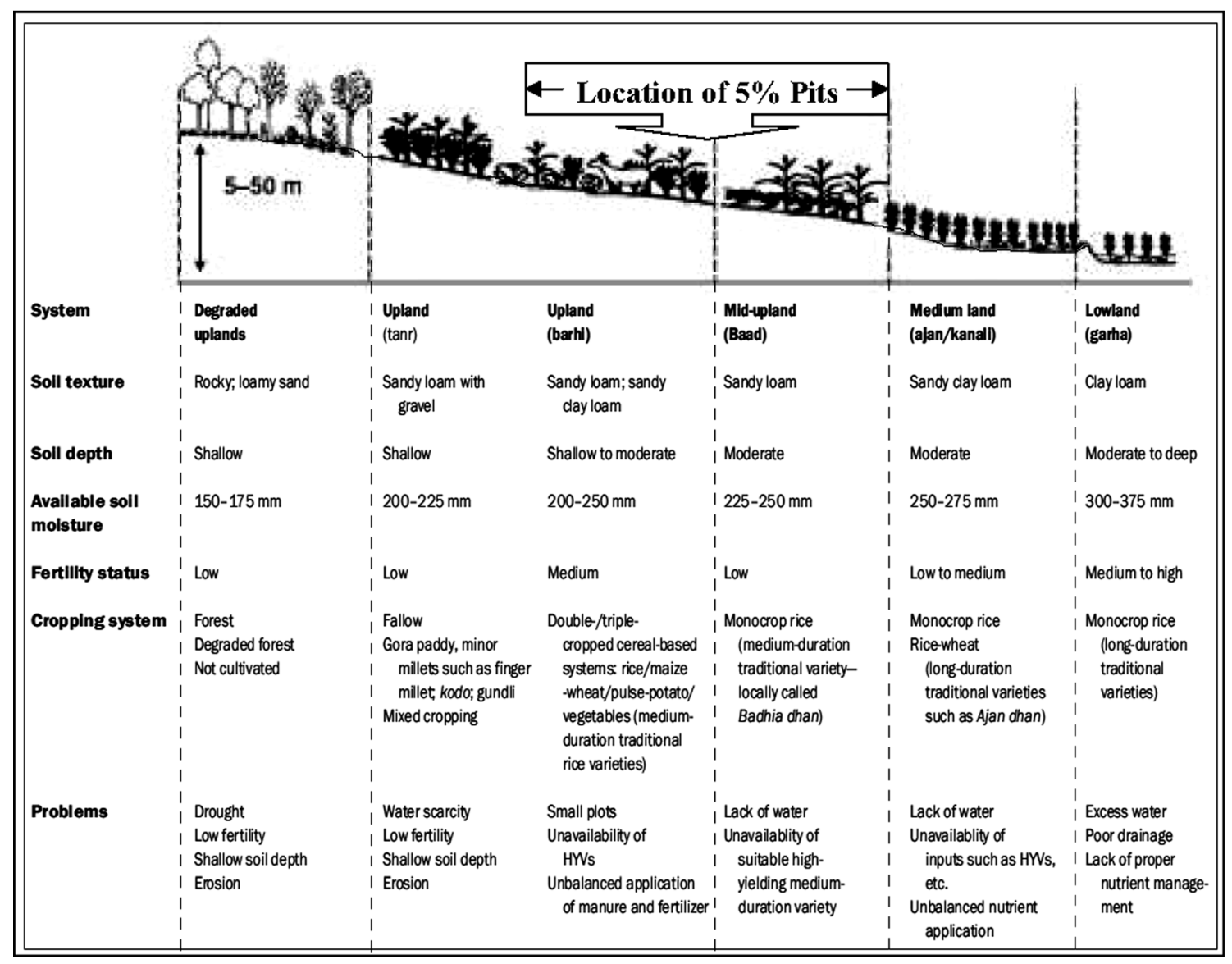

Fig. 2 Typical distribution of land types in Kumari river basin. Source: Modified after Banik et al. (2004)and Pangare (2003)

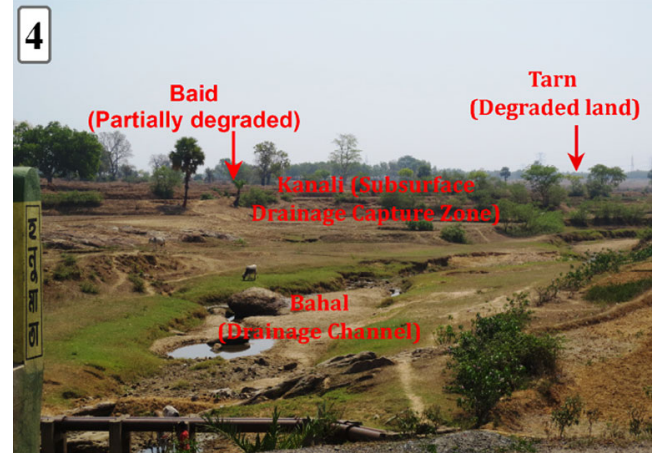

Plate 4 Types of land in Hanumata Basin, a sub-basin of Kumari River

enhancement of recharge rate. At present, remote sensing and GIS techniques provide reliable basic information about land use/land cover. In this study, for mapping of Land use/land cover patterns of the study area LISS-III satellite data (Liss-III 2012) has been used followed by intense field verification. For fulfilling the purpose of this study, only principal zones of similar response to recharge were encountered, thus only four zones of land cover/land use were defined (Fig. 3d). Water bodies and cultivated lands were assigned a high weightage because it is mostly associated with water body, which has been identified by the light blue tone, fine/medium texture. The barren or fallow lands and settlements which have poor water holding capacity have been given a medium weightage factor.

\section{Drainage}

Another input to evaluate the recharge property can be realized by detailed morphometric analysis of the drainage network. This character is determined fundamentally by the underlying lithology, and thus provides an important indication of water percolation rate (Shaban et al. 2006). It is well known that the denser the drainage network, the less recharge rate and vice versa. We all know that the extraction and analysis of the drainage network was used either from field data, topographic maps, aerial photographs, satellite images, or any combination of these. Though almost all researchers in this concern pointed out that manual extraction is more appropriate than the automated ones from satellite images (Tribe 1991; Ichoku et al. 1996; Martínez-Casasnovas and Stuiver 1998; Shaban et al. 2006). Therefore, in this study, a drainage map of Kumari 



Fig. 3 Factors effect on ground water potential zones of Kumari river basin. a Lithology; b Slope; c Lineament; d Land use and land cover; e Drainage density; f Soil 
Watershed was created manually from the topographic map (1: 50,000 scale) in order to calculate the drainage density (Fig. 3e). It is a measure of the total length of the stream segment of all orders per unit area. The drainage density is an inverse function of permeability. The less permeable a rock is, the less the infiltration of rainfall, which conversely tends to be concentrated in surface runoff. Which means a higher drainage density tends to indicate lower groundwater potential (Gumma and Pavelic 2012; Magesh et al. 2012; Selvam et al. 2012, 2014). For analysis purpose the drainage density of the study area has been grouped into five classes (Fig. 3e). Considering from recharge point of view more weightage is assigned to very low drainage density regions, whereas, low weightage assigned to very high drainage density.

\section{Soil}

Soil characteristics invariably control the infiltration of surface water into an aquifer system and they are directly interrelated to rates of infiltration and permeability, e.g. coarse textured soil are generally permeable while fine textured soils indicate less permeability. On the basis of this concept, Weights are assigned subjectively to each soil unit after taking into account the type of soil and its waterholding capacity. Soils in the district are in general of the residual type derived from the weathering of the Archaen granites, gneisses and schists. Four major soil units such as Lithic Ustochrepts, Typic Haplustalts, Lithic Ustorthents and Lithic Haplustalts, etc. are distributed across the study area (Plate 5). Details of those are shown in Fig. 3f and Table 2.

Six influencing factors, such as lithology, slope, land use, lineament, drainage, and soil have been identified to delineate the groundwater potential zones. Though, these factors do not have the same level of influence. So, in order to estimate the weights of the involved factors, the effect of these factors on each other must first be presented. According to Shaban et al. this was done through a

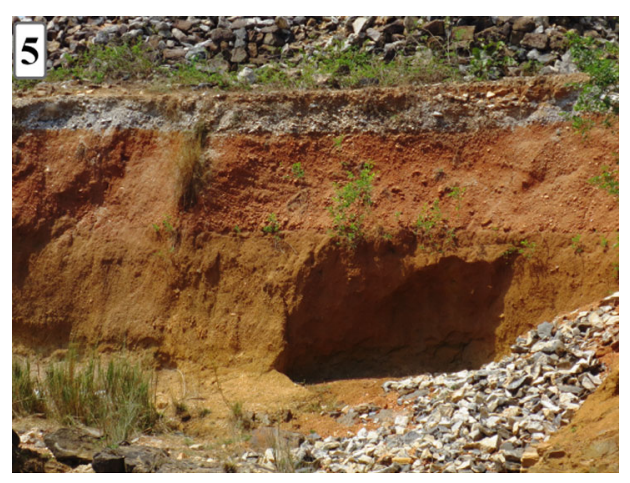

Plate 5 Red soil is the basic soil type in the study area schematic sketch (Fig. 4). Each relationship is classified into major with minor and weighted according to its potency.

The effect of each major and minor factor is assigned a weightage of 1.0 and 0.5 point respectively. The cumulative weightage of both major and minor effects are considered for calculating the relative rates (Table 3 ). This rate is further used to calculate the score of each influencing factor. The proposed score for each influencing factor is calculated by using the following formula

$\boldsymbol{S}=\left[\frac{(\boldsymbol{M} \boldsymbol{j}+\boldsymbol{M n})}{\sum(\boldsymbol{M} \boldsymbol{j}+\boldsymbol{M n})}\right] \times 100$

Where, $S$ is the proposed score of each influencing factor. $M j$ is major interrelationship between two factors and $M n$ is minor interrelationship between two factors.

The concerned score for each influencing factor was divided to each reclassified sub-factor (Table 4). The level of effect of these sub-factors is either expressed in numerical form, such as for the lineaments, drainage and soil, or in descriptive forms such as for the lithology and land use/land cover. For the numerical values, scores are given based on their values and for the descriptive forms; based on its influence on the recharging process. The representative weight of a factor of the potential zone is the sum of all weights from each factor. Finally, grid wise total potential scores were obtained according to percentage of area falling in different zone. Thus, a factor with a higher weight value shows a larger impact and a factor with a lower weight value shows a smaller impact on groundwater potential zones.

\section{Deciphering of groundwater potential zones and model evaluation}

The groundwater potential zones for the study area were generated through the integration of the grid wise weighted score of various thematic maps or multi influencing factor viz., drainage, slope, lithology, soil, lineament and land-use using remote sensing and GIS techniques. Finally, recharge potential zone map was prepared and divided the whole watershed into six levels or zones (Fig. 5), namely very good, good, moderate, poor, very poor and worst, occupying areas of 262.44, $557.18,430.24,368.66,123.56$, and $125.17 \mathrm{~km}^{2}$, respectively. That means about $33.07 \%$ of the total area have 'poor' groundwater potentiality, $23.04 \%$ falls under 'moderate' zone, and $43.89 \%$ have 'good' groundwater potentiality. According to the UN (1967), the recharge ability of these zones is as follows:

Very high $=45-50 \%$ of precipitated water is recharged to the subsurface strata.

$H i g h=30-35 \%$ of precipitated water is recharged to the subsurface strata. 
Table 2 Details of soil group in the study area

\begin{tabular}{lllcc}
\hline Map symbol & Taxonomic name & Description & Area $\left(\mathrm{km}^{2}\right)$ & Location in study area \\
\hline & Lithic Ustochrepts & Shallow, moderately well drained, coarse loamy soil & 133.19 & Moderate to good \\
& Typic Haplustalts & Deep, well drained, fine loamy soil & 1136.16 & Poor to moderate \\
\hline & Lithic Ustorthents & Very shallow, excessively drained, gravelly loamy Lateritic soil & 149.04 & Very poor \\
\hline & Lithic Haplustalts & Shllow, moderately well drained, gravelly loamy soil & 447.95 & poor
\end{tabular}

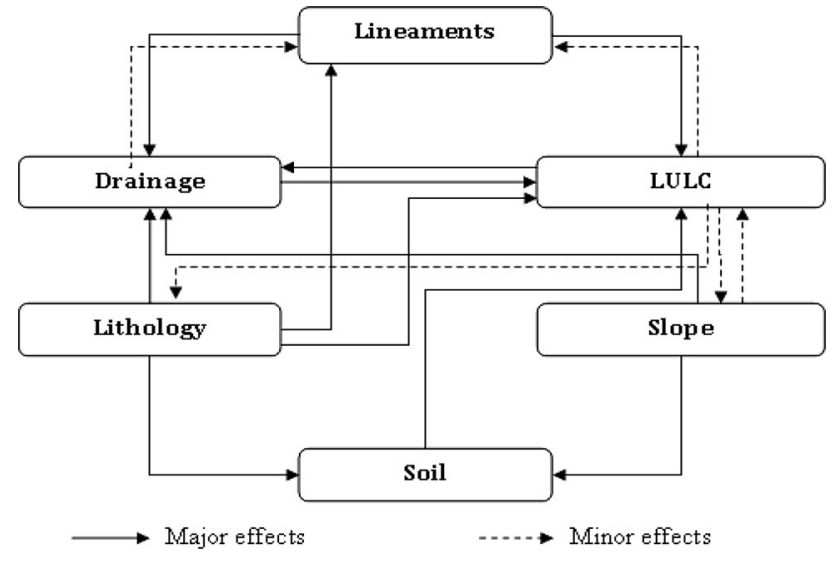

Fig. 4 Interrelationship between the multi influencing factors

Moderate $=10-20 \%$ of precipitated water is recharged to the subsurface strata.

Low $=5-10 \%$ of precipitated water is recharged to the subsurface strata.

Very low $=<5 \%$ of precipitated water is recharged to the subsurface strata.

The groundwater potential zone map was verified with the groundwater availability data (Table 1 ) to establish the validity of the model. Table 1 indicates that Manbazar and Barabazar has higher net groundwater availability than Balarampur and Bandoan as Manbazar and Barabazar situated in 'good' groundwater potential zone, while Balarampur and Bandoan situated in 'moderate, and 'poor' groundwater potential zone.
In order to measure the quantity of recharged water to subsurface media, a simplified calculation for the proposed recharge rates (adapted from UN 1967) and areal extent of recharge potential zones obtained in this study (Table 5):

As the average rainfall is $1330.8 \mathrm{~mm} /$ year (100 Years Rainfall Data Series, IMD 1901-2000), the volume of precipitated water of this basin will be around $2485 \times 10^{6} \mathrm{~m}^{3} /$ year. This is applied for five recharge potential zones to estimate total recharged water (W) as follows:

$$
\begin{aligned}
\mathrm{W}= & \text { Precipitated volume } \times \text { Recharge ratio } \times \% \text { of area } \\
\mathrm{W}= & 2485 \times 10^{6}\{(0.475 \times 0.141)+(0.325 \times 0.298) \\
& +(0.15 \times 0.23)+(0.075 \times 0.197)+(0.025 \times 0.133)\} \\
= & 537.5 \times 10^{6} \mathrm{~m}^{3} / \text { year }
\end{aligned}
$$

Which indicates that only $21.63 \%$ of precipitated water in Kumari watershed is infiltrating downward to recharge the groundwater reservoirs, whilst the rest of precipitation either evapo-transpirates or flow out as surface run off. That means there are scopes to harvest the rainwater to increase the store of groundwater.

\section{Methods of groundwater recharge}

The groundwater potential map (Fig. 5) demonstrates that the better groundwater potential zone is concentrated in the north-eastern and north-western region of the study area

Table 3 Proposed score of each influencing factor

\begin{tabular}{lllll}
\hline Influencing factors & Major effects $(\mathrm{Mj})$ & Minor effects $(\mathrm{Mn})$ & Total $(\mathrm{Mj}+\mathrm{MN})$ & Proposed score of each influencing factors \\
\hline Lineaments & $1+1$ & 0 & 2 & 15 \\
Land-use & 1 & $0.5+0.5+0.5$ & 2.5 & 19 \\
Lithology & $1+1+1+1$ & 0 & 4 & 29 \\
Drainage & 1 & 0.5 & 1.5 & 11 \\
Slope & $1+1$ & 0.5 & 2.5 & 19 \\
Soil & 1 & & 1 & 7 \\
& & $\sum 13.5$ & $\sum 100$ \\
\hline
\end{tabular}


Table 4 Classification of weighted factors influencing the potential zones

\begin{tabular}{|c|c|c|c|}
\hline Factor & Zone & Total weightage & Individual weightage \\
\hline \multirow[t]{5}{*}{ Lithology } & Mica schist and shale & 29 & 20 \\
\hline & Granite Gneiss Complex & & 15 \\
\hline & Quartzite & & 5 \\
\hline & Granite younger intrusive & & 3 \\
\hline & Recent alluvium & & 29 \\
\hline \multirow[t]{5}{*}{ Average slope $\left({ }^{\circ}\right)$} & Less than 2.00 & 19 & 19 \\
\hline & $2.01-3.00$ & & 15 \\
\hline & $3.01-4.00$ & & 11 \\
\hline & $4.01-5.00$ & & 7 \\
\hline & More than 5.00 & & 3 \\
\hline \multirow[t]{4}{*}{ Land use/land cover } & Water bodies & 19 & 19 \\
\hline & Vegetation & & 15 \\
\hline & Cultivated land & & 10 \\
\hline & Fallow land & & 5 \\
\hline \multirow[t]{5}{*}{ Lineament density $\left(\mathrm{km} / \mathrm{km}^{2}\right)$} & Less than 0.3 & 15 & 3 \\
\hline & $0.3-0.5$ & & 6 \\
\hline & $0.5-0.7$ & & 9 \\
\hline & $0.7-0.9$ & & 12 \\
\hline & More than 0.9 & & 15 \\
\hline \multirow[t]{5}{*}{ Drainage density $\left(\mathrm{km} / \mathrm{km}^{2}\right)$} & Less than 0.80 & 11 & 11 \\
\hline & $0.81-1.20$ & & 8 \\
\hline & $1.21-1.60$ & & 6 \\
\hline & $1.6-2.00$ & & 4 \\
\hline & More than 2.00 & & 2 \\
\hline \multirow[t]{4}{*}{ Soil } & Lithic Ustochrepts & 7 & 7 \\
\hline & Typic Haplustalts & & 5 \\
\hline & Lithic Ustorthents & & 3 \\
\hline & Lithic Haplustalts & & 4 \\
\hline
\end{tabular}

with high infiltration ability, while rest of the basin has poor to moderate potentiality to recharge groundwater. In that case, Rainwater harvesting may become a finest solution for groundwater recharge if implemented and worked out with utmost care and precision because the basin receives ample rainfall at monsoon times. The methods of groundwater recharge are:

Obstruction Check dam, Nalabund, Gully plugs, Khadin, Contour bunds

\begin{tabular}{ll}
\hline Storing & Percolation tanks, farm ponds, KT Weirs, Recharge pits \\
Injection & Inverted/recharge wells
\end{tabular}

Source: Krishna Murthy (ISRO); remote sensing and GIS applications in watershed management

In that case ' $5 \%$ pit technology' may be a useful method to increase the potentiality of groundwater as well as agricultural development. The term ' $5 \%$ technology' refers to a technique for harvesting rainwater and excess 
Table 5 Recharge potential categories and their quantitative estimation

\begin{tabular}{llllll}
\hline Recharge potentiality & Very high & High & Moderate & Low & Very low \\
\hline Proposed recharge rates & $45-50 \%$ & $30-35 \%$ & $10-20 \%$ & $5-10 \%$ & Less than 5\% \\
Average (\%) & 47.5 & 32.5 & 15.0 & 7.5 & 2.5 \\
Occupying study areas $\left(\mathrm{km}^{2}\right)$ & 262.44 & 557.18 & 430.24 & 368.66 & 248.73 \\
Area in \% & 14.05 & 29.84 & 23.04 & 19.75 & 13.32 \\
\hline
\end{tabular}

runoff initiated by Professional Assistance for Development Action (PRADAN) in the late 1990's in the Purulia district of West Bengal (Pangare 2003). It basically consists of a pit dug usually at the most upstream point on farmer's plot and represents roughly $5 \%$ of the total area of the plot. 'Baid' lands (Fig. 2) are most appropriate for $5 \%$ pit management.

\section{Conclusion}

No proper solution has been developed so far for groundwater development in the areas underlain by crystalline rocks. But at present, with the advent of remote sensing techniques, identification of the occurrences of groundwater has become a rapid and cost effective procedure. Integration of various geospatial information through Geoinformatics is very much essential for mapping of groundwater potential zones, as occurrence of groundwater at any place on the earth is a resultant effect of the interaction of the different factors like climatic, geology, hydrology etc. Present study has focused on the effectiveness of Remote Sensing and GIS in the identification and delineation of groundwater potential zones of Kumari River Basin, which is situated in drought prone western part of West Bengal, India. The identification of groundwater potential zone revealed that about $33.07 \%$ of the total study areas have 'poor' groundwater potentiality, $23.04 \%$ falls under 'moderate' zone, and $43.89 \%$ have 'good' groundwater potentiality. The alluvial tracts along the rivers and colluvial zones at the foot hill region have the better groundwater potentiality. On the other side, the regions with poor groundwater potential are spread mainly along linear ridges and lateritic uplands. If we compare the groundwater potential map with groundwater fluctuation map, then we will get the appropriate areas of artificial recharge. As the basin receives sufficient rainfall at monsoon months, rainwater harvesting and proper management of watershed may convert this virgin Kumari basin to fertile one. Hopefully in near future with the advancement of geoinformatics, "Ahalya Bhumi"- the land with a stony heart will become a myth in Purulia.

\section{References}

Acharya T, Nag SK (2013) Study of groundwater prospects of the crystalline rocks in Purulia District, West Bengal, India using remote sensing data. Earth Resour 1(2):54-59

Acharya T, Nag SK, Mallik SB (2012) Hydraulic significance of fracture correlated lineaments in precambrian rocks in Purulia District, West Bengal. J Geol Soc India 80:723-730

Antony RA (2012) Azimuthal square array resistivity method and groundwater exploration in Sanganoor, Coimbatore District, Tamilnadu, India. Res J Recent Sci 1(4):41-45

Baidya TK (1992) Apatite-magnetite deposit in the chhotanagpur gneissic complex, Panrkidih area, Purulia District, West Bengal. Indian J Geol 64(1):88-95

Banik P, Edmonds C, Fuwa N, Kam SP, Villano L, Bagchi DK (2004) Natural resource endowments, subsistence agriculture, and poverty in the Chhotanagpur Plateau. IRRI discussion paper series no. 47. International Rice Research Institute, Los Baños (Philippines). ISBN 971-22-0195-3, ISSN 0117-8180

Biswas A, Jana A, Sharma SP (2012) Delineation of groundwater potential zones using satellite remote sensing and geographic information system techniques: a case study from Ganjam district, Orissa, India. Res J Recent Sci 1(9):59-66

Carver S (1991) Integrating multi-criteria evaluation with geographic information systems. Int J Geogr Inf Sci 5(3):321-339

Chowdhury A, Jha MK, Chowdary VM (2010) Delineation of groundwater recharge zones and identification of artificial recharge sites in West Medinipur district, West Bengal, using RS, GIS and MCDM techniques. Environ Earth Sci 5:1209-1222

Das D (2000) GIS application in hydrogeological studies. doi:10. 1007/s10040-011-0703-8

Edet AE, Okereke CS, Teme SC, Esu EO (1998) Application of remote sensing data to groundwater exploration: a case study of the Cross River State, southeastern Nigeria. Hydrogeol J 6(3):394-404

Ganapuram S, Vijaya Kumar GT, Murali Krishna IV, Kahya E, Cüneyd Demirel M (2009) Mapping of groundwater potential zones in the Musi basin using remote sensing data and GIS. Adv Eng Softw 40:506-518

Gumma MK, Pavelic P (2012) Mapping of groundwater potential zones across Ghana using remote sensing, geographic information systems, and spatial modeling. Environ Monit Assess. doi:10.1007/s10661-012-2810-y

Haridas VR, Aravindan S, Girish G (1998) Remote sensing and its applications for groundwater favourable area identification. Q J GARC 6:18-22. http://www.gisdevelopment.net/application/nrm/ water/overview/wato0003.htm

Hutti B, Nijagunappa R (2011) Identification of groundwater potential zone using geoinformatics in Ghataprabha basin, North Karnataka, India. Int J Geomat Geosci 2(1):91-109

Ichoku A, Meisels A, Chorowicz J (1996) Detection of drainage channel networks on digital satellite images. Int J Remote Sens 17(9):1659-1678 
India Meteorological Department (IMD) 100 years (1901-2000) Monthly rainfall data series for districts, states and met subdivisions and all India, Hydrometeorology Division, Ministry of Earth and Science, Government of India

Jarvis A, Reuter HI, Nelson A, Guevara E (2008) Hole-filled seamless SRTM data V4, International Centre for Tropical Agriculture (CIAT). http://srtm.csi.cgiar.org

Kar B, Saha J, Saha JD (2012) Analysis of meteorological drought: the scenario of West Bengal. Indian J Spat Sci 3(2):1-11

Krishna Murthy YVN (ISRO) Remote sensing and GIS applications in watershed management. http://www.iirs.gov.in/iirs/sites/ default/files/pdf/Watershed_Director_IIRS.pdf

Kundu C (2004) Appraisal of water resources in the Kumari Basin. Geogr Rev India 66(3):254-263

Liss-III (2012) National Remote Sensing Centre. ISRO, Government of India, Hyderabad

Magesh NS, Chandrasekar N, Soundranayagam JP (2012) Delineation of groundwater potential zones in Theni district, Tamil Nadu, using remote sensing, GIS and MIF techniques. Geosci Front 3(2):189-196

Martínez-Casasnovas JA, Stuiver HJ (1998) Automatic delineation of drainage networks and elementary catchments from Digital Elevation Models. Int J Aerosp Surv Earth Sci (ITC J). 1998-3/ 4:198-208

Nag SK (2005) Application of lineament density and hydrogeomorphology to delineate groundwater potential zones of Bagmundi Block in Purulia District, West Bengal. J Indian Soc Remote Sens 33(4):521-529

O'Leary DW, Friedman JD, Poh HA (1976) Lineaments, linear, lineations: some standards for old terms. Geol Soc Am Bull 87:1463-1469

Pangare V (2003) 5\% pit technology technical report, Purulia, West Bengal, India. Poverty-focused smallholder water management: an IWMI research project supported by DFID. Final report document 6 of 9. International Water Management Institute (IWMI)

Rokade VM, Kundal P, Joshi AK (2007) Groundwater potential modeling through remote sensing and GIS: a case study of Rajura Taluka, Chandrapur District, Maharashtra. J Geol Soc India 69(5):943-948

Roy AK (1969) Geohydrological set-up of Eastern India. Indian Geohydrol 5(1):65-70

Roy D, Chakraborti S (2007) Regional geochemical mapping of a part of Singhbhum mobile belt and Chhotanagpur Gneissic complex, Purulia District, West Bengal (final report), code no. GCM/ER/ WSA/2002/002. Geological Survey of India, Government of India
Salman AA (1983) Using landsat imagery interpretation prospection around Qena providence, Egypt. Int J Remote Sens 4:1489-1497

Saraf AK, Chaudhuray PR (1998) Integrated remote sensing and GIS for groundwater exploration and identification of artificial recharge sites. Int J Remote Sens 19(10):1825-1841

Selvam G, Banukumar K, Srinivasan D, Selvakumar R, Alaguraja P (2012) Identification of ground water potential zone in hard rock terrain - a case study from parts of Manapparai block Tamilnadu using remote sensing and GIS techniques. Int J Adv Remote Sens GIS 1(1):8-18

Selvam S, Magesh NS, Sivasubramanian P, Soundranayagam JP, Manimaran G, Seshunarayana T (2014) Deciphering of groundwater potential zones in Tuticorin, Tamil Nadu, using remote sensing and GIS techniques. J Geol Soc India 84:597-608

Shaban A, Khawlie M, Abdallah C (2006) Use of remote sensing and GIS to determine recharge potential zone: the case of Occidental Lebanon. Hydrogeol J 14(4):433-443

Sharma R (2009) Craton and fold belts of India, lecture notes in earth sciences, vol 127. Springer, New York. doi:10.1007/978-3-64201459-8_2

State Action Plan on Climate Change, West Bengal (2011) Ministry of environment and forests, Government of West Bengal, India

Subba Rao N, Chakradhar GKJ, Srinivas V (2001) Identification of groundwater potential zones using remote sensing techniques in and around Guntur town, Andhra Pradesh, India. Photonirvaehak J Indian Soc Remote Sens 29(1, 2):69-78

Teeuw RM (1994) Groundwater exploration using remote sensing and a low-cost geographic information system. Hydrogeol J $3(3): 21-30$

Thomas A, Sharma PK, Sharma MK, Sood Anil (1999) Hydrogeomorphological mapping in assessing groundwater by using remote sensing datada case study in Lehra Gage Block, Sangrur district, Punjab. J Indian Soc Remote Sens 27:31-42

Tiwari A, Rai B (1996) Hydromorphological mapping for groundwater prospecting using landsat-MSS images - a case study of Part of Dhanbad District, Bihar. J Indian Soc Remote Sens 24:281-285

Todd DK, Mays LW (2005) Groundwater hydrology, 3rd edn. Wiley, New York ISBN: 978-0-471-05937-0

Tribe A (1991) Automated recognition of valley heads from digital elevation models. Earth Surf Process Landf 16(1):33-49

UN (1967) Hydrogeologic map of Lebanon. Carte hydrog eologique du Liban au 1/100000me, UN, Beyrouth, Liban 